\title{
Combining Marandu grass grazing height and supplementation level to optimize growth and productivity of yearling bulls
}

\author{
R.P. Barbero ${ }^{\mathrm{a}, *}$, E.B. Malheiros ${ }^{\mathrm{a}}$, T.L.R. Araújo ${ }^{\mathrm{b}}$, R.L.G. Nave $^{\mathrm{c}}$, J.T. Mulliniks ${ }^{\mathrm{d}}$, \\ T.T. Berchielli ${ }^{\text {b }}$, A.C. Ruggieri ${ }^{\text {b }}$, R.A. Reis ${ }^{\mathrm{b}}$ \\ a Departamento de Ciências Exatas, Faculdade de Ciências Agrárias e Veterinárias, UNESP - Univ Estadual Paulista, \\ 14884-900 Jaboticabal, SP, Brazil \\ b Departamento de Zootecnia, Faculdade de Ciências Agrárias e Veterinárias, UNESP - Univ Estadual Paulista, 14884-900 Jaboticabal, \\ SP, Brazil \\ c Department of Plant Sciences, The University of Tennessee, 37996 Knoxville, TN, USA \\ d Department of Animal Science, The University of Tennessee, 37996 Knoxville, TN, USA
}

\section{A R T I C L E I N F O}

\section{Article history:}

Received 27 February 2015

Received in revised form

15 September 2015

Accepted 16 September 2015

\section{Keywords:}

Beef cattle

Grazing height

Methane

Performance

Supplementation

\begin{abstract}
A B S T R A C T
Two experiments were conducted to determine the effects of grazing height and supplementation levels of Marandu pastures on average daily gain (ADG), gain per hectare (GPH) and methane $\left(\mathrm{CH}_{4}\right)$ emissions during the wet season under continuous stocking by Nelore yearling bulls. Exp. 1: three grazing heights were evaluated: 15,25 and $35 \mathrm{~cm}$, combined with $0.3 \%$ of BW of a supplement (161 g crude protein (CP)/ $\mathrm{kg}$ and $20.1 \mathrm{MJ}$ gross energy $(\mathrm{GE}) / \mathrm{kg}$ on dry matter basis (DMB)). Experimental design was completely randomized (three paddocks per treatment), and the effects were analyzed by polynomial orthogonal contrasts. Exp. 2: grazing heights were combined with decreasing supplementation levels as grazing heights increased: short height $(15 \mathrm{~cm})$ and high supplementation $(0.6 \%$ of BW of a supplement: $142 \mathrm{~g} \mathrm{CP} / \mathrm{kg}$ and $18.9 \mathrm{MJ} \mathrm{GE} / \mathrm{kg}$ on DMB) (SHHS); moderate height $(25 \mathrm{~cm})$ and moderate supplementation ( $0.3 \%$ of BW of a supplement: $161 \mathrm{~g} \mathrm{CP} / \mathrm{kg}$ and $20.1 \mathrm{MJ} \mathrm{GE} / \mathrm{kg}$ on DMB) (MHMS) or tall height $(35 \mathrm{~cm}$ ) without supplementation) (THWS). Experimental design was completely randomized (three paddocks per treatment), and treatment means were compared by Tukey test $(P<0.05)$. In Exp. 1 , ADG increased linearly $(P=0.02)$, and GPH decreased linearly $(P=0.0002)$ as grazing height increased. Methane emission was not affected $(P=0.64)$ by grazing height. In Exp. 2, ADG was not influenced $(P=0.14)$ by treatments. However, GPH was the greatest $(P<0.0001)$ for the SHHS treatment. In addition, $\mathrm{CH}_{4}$ emissions were lower $(P<0.0001)$ in SHHS and MHMS bulls compared to THWS. The SHHS
\end{abstract}

\footnotetext{
Abbreviations: ADF, acid detergent fiber (expressed inclusive of residual ash); aNDF, neutral detergent fiber (assayed with a heat stable amylase and expressed inclusive of residual ash); ADG, average daily gain; AU, animal unit; BW, body weight; CP, crude protein; DM, dry matter; DMB, dry matter basis; DMI, dry matter intake; GPH, gain per hectare; ha, hectare; GE, gross energy; IVOMD, in vitro organic matter digestibility; IVDMD, in vitro dry matter digestibility; MHMS, moderate height and moderate supplementation; ME, metabolizable energy; OM, organic matter; SHHS, short height and high supplementation; THWS, tall height without supplementation.

* Corresponding author at: Departamento de Ciências Exatas, Universidade Estadual Paulista (UNESP), Via de acesso Prof. Paulo Donato Castellane, km 5, 14884-900 Jaboticabal, SP, Brazil.

E-mail address: rondinelibarbero@zootecnista.com.br (R.P. Barbero).
} 
can improve the GPH without decreasing the ADG of each individual animal. Optimizing supplementation level according to grazing pressure may improve the nutrition efficiency on beef cattle production by decreasing the $\mathrm{CH}_{4} / \mathrm{ADG}$ and $\mathrm{MJ} \mathrm{CH}_{4} / \mathrm{MJ}$ metabolizable energy intake.

(c) 2015 Elsevier B.V. All rights reserved.

\section{Introduction}

Beef cattle production in Brazil is highly dependent on forage-based grazing systems. Therefore, strategically well-planned grazing systems are critical to optimize beef production. According to Da Silva et al. (2013), grazing height alters average daily gain (ADG) and body weight (BW) gain per hectare (GPH). From the production model proposed by Mott (1960), low stocking rate will result in high grazing height, high herbage allowance, high dry matter (DM) intake (DMI) and high ADG, but results in low GPH. Pastures with higher stocking allow greater GPH despite the low grazing height, low DMI and low ADG (Jones and Sandland, 1974). However, it is possible to increase both ADG and GPH simultaneously, but supplementation may be necessary (Sollenberger and Vanzant, 2011).

In studies with beef cattle production in tropical grasses, pastures managed with high grazing height under continuous stocking showed low response of ADG to supplementation (De Oliveira et al., 2015), possibly compromising the economic return from supplementation costs. However, at high grazing intensity when a lower grazing height is used, additional supplementation can promote an increased ADG and GPH (Reis et al., 2013). Therefore, supplementation regimes have to be adjusted according to available herbage, with higher supplement levels in lower grazing height and lower levels in higher grazing height.

Studies showing the combined effects of grazing intensity and supplementation on efficiency of beef cattle production grazing tropical grasslands are scarce. The hypothesis of this study was that grazing height will alter the productive parameters, but supplementation according to grazing height could result in a simultaneous increase of ADG and GPH, improving production efficiency and energy utilization. The objective of this study was to determine the effect of grazing height in Marandu pastures combined with supplementation level for beef cattle, evaluating the ADG, GPH and methane $\left(\mathrm{CH}_{4}\right)$ emissions during the summer (wet season).

\section{Material and methods}

Two experiments were conducted simultaneously at the Forages and Grasslands division of the Sao Paulo State University “Julio de Mesquita Filho" (UNESP), in Jaboticabal, SP, Brazil $\left(21^{\circ} 15^{\prime} 22^{\prime \prime}\right.$ S latitude, $48^{\circ} 18^{\prime} 58^{\prime \prime} 77 \mathrm{~W}$ longitude and $595 \mathrm{~m}$ elevation). The typical climate is humid subtropical, mild, dry winters and hot, wet summers. The pastures used in the study site were planted in 2001 with Brachiaria brizantha (Hochst ex A. Rich) Stapf cv. Marandu, divided into 18 paddocks with area: 0.7 ha $(n=6), 1.0$ ha $(n=6)$ and 1.3 ha $(n=6)$.

Experiments were conducted during the wet season 2012/2013. Grazing heights were established in the period from November 26, 2012 to January 11, 2013, animal adaptation to experimental conditions occurred from January 12 to January 26, 2013 (14 days). Maintenance fertilizer was applied to all paddocks at $180 \mathrm{~kg} \mathrm{~N}: \mathrm{P}_{2} \mathrm{O}_{5}: \mathrm{K}_{2} \mathrm{O}(4: 14: 8) /$ ha on December 10, 2012. Urea was applied at $160 \mathrm{~kg} \mathrm{~N} / \mathrm{ha}$, split among three applications, according to precipitation schedule: December 27, 2012, January 22, 2013 and February 26, 2013.

\subsection{Animals and treatments}

\subsubsection{Experiment 1}

The experiment consisted of three treatments (grazing heights), with three replications, totaling 9 experimental paddocks with a completely randomized design. Sixty Nelore yearling bulls with an initial BW of $335 \pm 6.3 \mathrm{~kg}$ were utilized. Bulls were identified, weighed and randomly distributed in groups of six bulls per paddock. The remaining animals were used to maintain grazing height that was pre-determined, using the put-and-take methodology (Mott and Lucas, 1952). The procedures above described were approved by the Institutional Animal Care and Use Committee, from UNESP.

Grazing heights were: 15,25 and $35 \mathrm{~cm}$. Paddocks were managed under continuous stocking and areas were 0.7, 1.0, and 1.3 ha for 15,25 and $35 \mathrm{~cm}$ grazing heights, respectively. The variation in paddock size was placed to maintain the same number of animals per paddock. Bulls received a supplement containing $161 \mathrm{~g}$ of crude protein $(\mathrm{CP}) / \mathrm{kg}$ on dry matter basis (DMB) and $20.1 \mathrm{MJ}$ gross energy (GE)/kg on DMB offered at $0.3 \%$ of average BW, which was formulated based on the herbage chemical composition previously analyzed, aiming to achieve $1 \mathrm{~kg} /$ day ADG (NRC, 1996) (Table 1). Supplements were provided daily at 11:00 AM.

\subsubsection{Experiment 2}

This experiment utilized 60 Nelore yearling bulls with an initial BW of $336 \pm 5.7 \mathrm{~kg}$. The animals were identified, weighed and randomly distributed in groups of 6 animals per paddock, with the experiment consisting of three treatments and three 
Table 1

Ingredients and chemical composition of supplements for yearling bulls grazing Marandu grass pastures during the wet season.

\begin{tabular}{|c|c|c|c|}
\hline \multirow[t]{2}{*}{ Item } & \multicolumn{3}{|c|}{ Supply level (\% BW) } \\
\hline & $\mathrm{MM}^{\mathrm{a}}$ & 0.3 & 0.6 \\
\hline \multicolumn{4}{|l|}{ Ingredients } \\
\hline Citrus pulp (g/kg DM) & - & 380 & 470 \\
\hline Ground corn (g/kg DM) & - & 230 & 235 \\
\hline Cotton meal (g/kg DM) & - & 310 & 230 \\
\hline Mineral nucleus (g/kg DM) & 1000 & 80.0 & 65.0 \\
\hline \multicolumn{4}{|l|}{ Chemical composition } \\
\hline Calcium (g/kg DM) & 145 & 16.0 & 10.0 \\
\hline Phosphorus (g/kg DM) & 80.0 & 6.00 & 4.00 \\
\hline Magnesium (g/kg DM) & 10.0 & 1.00 & 0.50 \\
\hline Sulfur (g/kg DM) & 40.0 & 3.00 & 1.50 \\
\hline Sodium (g/kg DM) & 130 & 13.0 & 7.00 \\
\hline Crude protein (g/kg DM) & - & 161 & 142 \\
\hline aNDF (g/kg DM) & - & 144 & 158 \\
\hline $\mathrm{ADF}(\mathrm{g} / \mathrm{kg} \mathrm{DM})$ & - & 83.9 & 92.0 \\
\hline GE (MJ/kg DM) & - & 20.1 & 18.9 \\
\hline IVDMD (g/kg DM) & - & 822 & 793 \\
\hline IVOMD (g/kg DM) & - & 848 & 826 \\
\hline
\end{tabular}

Body weight (BW), dry matter (DM), neutral detergent fiber (aNDF), acid detergent fiber (ADF), gross energy (GE), in vitro dry matter digestibility (IVDMD) and in vitro organic matter digestibility (IVOMD).

a Mixed mineral (MM), supplied ad libtum.

replications, totaling 9 experimental paddocks. The remaining animals were used to maintain grazing height that was predetermined, using the put-and-take methodology (Mott and Lucas, 1952). The procedures adopted were approved by the Institutional Animal Care and Use Committee, from UNESP.

The same three grazing heights $(15,25$ and $35 \mathrm{~cm})$ utilized in Exp. 1 were evaluated under continuous stocking, combined with decreasing supplementation levels as grazing height increased. Supplementation and grazing strategies were: short height $(15 \mathrm{~cm})$ and high supplementation ( $0.6 \%$ of BW of a supplement: $142 \mathrm{~g} \mathrm{CP} / \mathrm{kg}$ and $18.9 \mathrm{MJ} \mathrm{GE} / \mathrm{kg}$ on DMB) (SHHS), moderate height $(25 \mathrm{~cm})$ and moderate supplementation $(0.3 \%$ of BW of a supplement: $161 \mathrm{~g} \mathrm{CP} / \mathrm{kg}$ and $20.1 \mathrm{MJ} \mathrm{GE} / \mathrm{kg}$ on DMB) (MHMS), or tall height $(35 \mathrm{~cm})$ without additional supplementation (THWS). The supplements were formulated based on the herbage chemical composition previously analyzed, aiming to achieve a $1 \mathrm{~kg} /$ day ADG (NRC, 1996), except no supplementation (Table 1). Supplements were provided daily at 11:00 AM on feeders located in each paddock. The paddocks area varied to maintain the same number of animals per paddock, as described in the first experiment.

\subsection{Herbage sampling}

Grazing heights were measured weekly at 80 random points ("hits")/hectare (ha) to estimate average paddock height. To estimate herbage mass, 8 samples per paddock (average spots height) were collected from a $0.25 \mathrm{~m}^{2}$ area $(5 \mathrm{~cm}$ residual height) every 28 days (January to April 2013). Samples were then separated into dead material, stem + leaf sheath and green leaves, dried at $55 \pm 5^{\circ} \mathrm{C}$ to constant weight to estimate $\mathrm{DM} / \mathrm{ha}$. To estimate herbage nutritive value, samples were handplucked in the same periods ( 20 average spots heights each paddock), dried at $55 \pm 5^{\circ} \mathrm{C}$ to constant weight then ground through a 1-mm screen in a shear mill (Thomas-Wiley Laboratory Mill Model 4, H. Thomas Co.) for analyses.

\subsection{Chemical analyses}

Dry matter (DM: AOAC 934.01) and organic matter (OM: AOAC 942.05) were determined according to procedures from AOAC (1990). Crude protein was determined using LECO ${ }^{\circledR}$ FP 528 (Leco Corporation, MI, USA). Neutral detergent fiber by adding alpha-amylase without the addition of sodium sulfite (aNDF) and acid detergent fiber (ADF) analysis were based on the procedures described by Mertens (2002), using polyester filter bags and equipment ANKOM ${ }^{\circledR}$ (Ankom technologies, NY, USA). Both, aNDF and ADF were expressed inclusive of residual ash. In vitro DM digestibility (IVDMD) and in vitro OM digestibility (IVOMD) were determined after $48 \mathrm{~h}$ incubation period using the ANKOM $^{\circledR}$, Daisy ${ }^{\text {II }}$ methodology (Ankon technologies, NY, USA), with diluted rumen liquor ( $25 \%$ of rumen liquor) from yearling bulls grazing Marandu grass, receiving energy-protein and mixed mineral supplementation. Such as Fiorentini et al. (2013), the GE was determined using adiabatic bomb calorimetric (PARR Instrument Company 6300, IL, USA).

\subsection{Intake estimation}

Intake was estimated using three markers to determine fecal excretion, DMI of supplement, herbage and total DMI. To determine fecal excretion, the external lignin isolated marker, purified and enriched from Eucalyptus grandis, was orally administered daily $(500 \mathrm{mg}$ ) during six days, with three days to stabilize fecal excretion of the marker, and in the last three 
days for sample collection, every $12 \mathrm{~h}$ (Santos et al., 2011). Feces were dried at $55 \pm 5^{\circ} \mathrm{C}$ for $72 \mathrm{~h}$ and pooled in animal basis to analyze the lignin marker concentration using the infrared spectroscopy method (Saliba et al., 2013).

To estimate DMI of supplement, titanium dioxide $\left(\mathrm{TiO}_{2}\right)$ was added as external marker to the supplement at a rate of $10 \mathrm{~g} /$ day of $\mathrm{TiO}_{2}$ per animal $(10 \mathrm{~g} /$ day $\times$ no. of bulls/paddock) during 9 days, with six days to stabilize fecal excretion of the marker, and in the last three days for sample collection, every $12 \mathrm{~h}$ (Titgemeyer et al., 2001). Feces samples were taken during the same time of the fecal excretion procedures. Feces were dried at $55 \pm 5^{\circ} \mathrm{C}$ for $72 \mathrm{~h}$, to constant weight, pooled in animal basis, ground and digested using sulfuric acid. A standard curve was prepared adding $0,2,4,6,8$ and $10 \mathrm{mg} \mathrm{of} \mathrm{TiO}_{2}$, through spectrophotometry read at $410 \mathrm{~nm}$ as described by Myers et al. (2004). Individual supplement intake was estimated using the following equation:

$$
\text { Supplement DMI }=\frac{\text { [g of } \left.\mathrm{TiO}_{2} / \mathrm{g} \text { of feces }\right] \times \text { fecal excretion }}{[\mathrm{g} \mathrm{TiO} / 2 / \text { of supplement }]}
$$

Herbage DMI was estimated using as internal marker undigested aNDF, determined by ruminal incubation (Nocek and English, 1986) for $240 \mathrm{~h}$ (Casali et al., 2008). Herbage DMI was estimated from the fecal output of the internal marker corrected for the supplement contribution as follows:

$$
\text { Herbage DMI }=\frac{\mathrm{FE} \times[i \mathrm{MF}]-\mathrm{DMIS} \times[i \mathrm{MS}]}{[i \mathrm{MH}]}
$$

where FE is the fecal excretion, DMIS is the DMI of supplement, [iMF], [iMS] and [iMH] are the concentrations of the internal marker in feces, supplement and herbage, respectively. Total DMI was obtained by addition of herbage and supplement DMI.

To determinate metabolizable energy (ME) intake, energy digestibility was calculated considering the GE intake (from herbage + supplement) and the energy lost in the feces by the equation:

$$
\text { Energy digestibility }=\frac{\text { GE intake }- \text { GE fecal excretion }}{\text { GE intake }} .
$$

Metabolizable energy was estimated by the equation (NRC, 1996):

$$
\mathrm{ME}=\text { Energy digestibility } \times 0.82 .
$$

\subsection{Enteric methane}

Enteric $\mathrm{CH}_{4}$ through eructation was measured using the gas sulfur hexafluoride $\left(\mathrm{SF}_{6}\right.$ ) method (Johnson et al., 1994). Capsules with constant release of $\mathrm{SF}_{6}$ were inserted orally into the rumen. The sampling apparatus consisted of a polyvinyl chloride collection vessel and a capillary tube extending from the collection canister to just above the mouth and nostrils of the animals. The canister was attached to a collar around the neck of the bull. To initiate sample collection, the attached canister was connected to the transfer line, and a valve on the collection vessel was opened. The collection vessel was changed daily during 6 consecutive days. A gas chromatograph was used to analyze $\mathrm{CH}_{4}$ and $\mathrm{SF}_{6}$ concentration.

Enteric $\mathrm{CH}_{4}$ animal emission was calculated in proportion to $\mathrm{SF}_{6}$ emission through the rumen capsule, subtracting environmental $\mathrm{CH}_{4}$ as follows:

$$
\mathrm{CH}_{4}=\mathrm{C}_{\mathrm{SF}_{6}} \times\left(\left[\mathrm{CH}_{4}\right]_{v}-\left[\mathrm{CH}_{4}\right]_{E n}\right) /\left[\mathrm{SF}_{6}\right]_{v}
$$

where $\mathrm{CH}_{4}$ is the $\mathrm{CH}_{4}$ emission tax by animal, $\mathrm{C}_{\mathrm{SF}_{6}}$ is the $\mathrm{SF}_{6}$ emission from capsule in rumen, $\left[\mathrm{CH}_{4}\right]_{v}$ is the $\mathrm{CH}_{4}$ concentration at collection vessel, $\left[\mathrm{CH}_{4}\right]_{E n}$ is the methane concentration in the environment and $\left[\mathrm{SF}_{6}\right]_{v}$ is the $\mathrm{SF}_{6}$ concentration at collection vessel.

\subsection{Animal production}

The experiment period was 84 days. The bulls were weighed at the beginning and end of the experiment in fasting $(12 \mathrm{~h})$. The productive parameters were calculated using the equations:

$$
\begin{aligned}
& \mathrm{BW} \text { gain }(\mathrm{kg})=\mathrm{BW}_{\text {final }}-\mathrm{BW}_{\text {initial }} ; \\
& \mathrm{ADG}=\mathrm{BW} \text { gain }(\mathrm{kg}) / 84(\text { days }) ; \\
& \mathrm{GPH}=(\mathrm{ADG} \times 6(\text { animals }) \times 84(\text { days })) / \mathrm{area}(\mathrm{ha}) ; \\
& \text { Stocking rate in animal unit }(\mathrm{AU}=450 \mathrm{~kg} \mathrm{BW}) / \mathrm{ha}=\left(\sum \mathrm{BW}_{\text {mean }} / 450\right) / \text { area }(\mathrm{ha}) ; \\
& \text { Herbage mass availability }(\mathrm{kg} \mathrm{DM} / \mathrm{kg} \mathrm{BW})=(\mathrm{kgDM} / \mathrm{ha}) /\left(\sum \mathrm{BW}_{\text {mean }} / \text { area }(\text { ha })\right) .
\end{aligned}
$$

The bulls were weighed without fasting, every 28 days to adjust supply of supplements (\% BW). 
Table 2

Characteristics of Marandu grass pastures at different grazing height during the wet season.

\begin{tabular}{|c|c|c|c|c|c|c|}
\hline \multirow[t]{2}{*}{ Item } & \multicolumn{3}{|c|}{ Grazing height $(\mathrm{cm})$} & \multirow[t]{2}{*}{ SEM } & \multirow[t]{2}{*}{ Effect } & \multirow[t]{2}{*}{$P$ value } \\
\hline & 15 & 25 & 35 & & & \\
\hline \multicolumn{7}{|l|}{ Herbage characteristics } \\
\hline Herbage mass (kg/ha) & 5994 & 7735 & 11,016 & 271 & Quadratic & 0.03 \\
\hline Green leaves $(\mathrm{g} / \mathrm{kg})$ & 433 & 409 & 385 & 32.4 & Linear & $<0.0001$ \\
\hline Stem + sheath $(\mathrm{g} / \mathrm{kg})$ & 395 & 431 & 478 & 57.3 & Linear & $<0.0001$ \\
\hline Dead material (g/kg) & 172 & 160 & 138 & 24.8 & Linear & $<0.0001$ \\
\hline Availability $^{\mathrm{a}}$ (kg DM/kg BW) & 1.90 & 3.41 & 6.32 & 0.27 & Quadratic & 0.001 \\
\hline Availability $^{\mathrm{b}}$ (kg DM/kg BW) & 0.83 & 1.42 & 2.47 & 0.23 & Linear & $<0.0001$ \\
\hline \multicolumn{7}{|l|}{ Herbage composition } \\
\hline $\mathrm{OM}$ (g/kg DM) & 910 & 925 & 924 & 18.4 & Quadratic & 0.01 \\
\hline $\mathrm{CP}(\mathrm{g} / \mathrm{kg} \mathrm{DM})$ & 151 & 139 & 137 & 4.85 & ns & 0.19 \\
\hline aNDF (g/kg DM) & 577 & 600 & 595 & 44.7 & ns & 0.07 \\
\hline $\mathrm{ADF}(\mathrm{g} / \mathrm{kg} \mathrm{DM})$ & 289 & 293 & 297 & 32.1 & ns & 0.44 \\
\hline IVDMD (g/kg DM) & 684 & 669 & 646 & 12.1 & Linear & 0.02 \\
\hline IVOMD (g/kg DM) & 717 & 705 & 677 & 14.2 & Linear & 0.02 \\
\hline GE (MJ/kg DM) & 16.1 & 16.0 & 15.8 & 0.15 & Linear & 0.04 \\
\hline
\end{tabular}

Dry matter (DM), body weight (BW), organic matter (OM), crude protein (CP), neutral detergent fiber (aNDF), acid detergent fiber (ADF), in vitro dry matter digestibility (IVDMD), in vitro organic matter digestibility (IVOMD), gross energy (GE), standard error of mean (SEM) and non-significative (ns).

a Total herbage availability.

b Green leaves herbage availability.

\subsection{Statistical analyses}

Means of each data type collected were calculated for each paddock in both experiments. The experimental design was completely randomized. The statistical analyses accounted for three treatments and three replications per treatment $(n=9)$. Normality of errors and homoscedasticity of data were verified by PROC UNIVARIATE procedures of SAS ${ }^{\circledR}$ (SAS Inst. Inc., Cary, NC, 2008). The mathematical model was represented by:

$$
Y_{i j}=\mu+T R_{i}+\varepsilon_{i j}
$$

where Y $i j$ is the dependent variable, $\mu$ is the general average effect, TR $i$ is the treatment effect " $i$ ", " $j$ " are the paddock effect, and $\varepsilon_{i j}$ is the random error. In the Exp.1, the grazing height effects were analyzed by polynomial orthogonal contrasts. In the Exp. 2 treatments were contrasted using Tukey test $(P<0.05)$ utilizing the PROC MIXED of SAS ${ }^{\circledR}$ (SAS Inst. Inc., Cary, NC, 2008).

\section{Results}

\subsection{Experiment 1}

Weekly grazing height measurements and put-and-take stocking rate adjustments resulted in grazing heights of $15.1 \pm 0.3,25.3 \pm 0.8$ and $35.4 \pm 1.5 \mathrm{~cm}$, corresponding to the predetermined treatments of 15,25 , and $35 \mathrm{~cm}$ of grazing height, respectively. Herbage mass characteristics are shown in Table 2. Herbage mass was influenced by grazing height (quadratic; $P=0.03)$. Green leaves and dead material as proportion of the herbage biomass $(\mathrm{g} / \mathrm{kg})$ exhibited a linear response $(P<0.0001)$, decreasing as grazing height increased. The proportion of stem + leaf sheath increased linearly with grazing height $(P<0.0001)$. Total herbage mass availability exhibited a quadratic response $(P=0.001)$. The increase in grazing height influenced green leaves mass availability (linear; $P<0.0001$ ), altering some of the chemical composition characteristics of the grass taken via simulated grazing. Grazing height did not affect $\mathrm{CP}(P=0.19)$, aNDF $(P=0.07)$ and ADF $(P=0.44)$. However, grazing height did influence OM (quadratic; $P=0.01$ ), GE (linear; $P=0.04$ ), IVDMD (linear; $P=0.02$ ) and IVOMD (linear; $P=0.02$ ).

Table 3 shows the intake, animal production and methane emissions results. Stocking rate exhibited a quadratic response $(P=0.05)$. Dry matter herbage intake and total DMI were affected by grazing height, showing a positive linear response $(P=0.02$ and 0.03 , respectively). Metabolizable energy intake and the ratio of CP intake to IVOMD intake were not affected $(P=0.19$ and 0.21 , respectively). Average daily gain showed a positive linear response, increasing $(P=0.02)$ with grazing height. However, GPH $(P=0.0002)$ and $\mathrm{CH}_{4} /$ ha/day $(P=0.001)$ showed a negative linear response, decreasing as grazing height increased. Grazing height did not influence $(P \geq 0.09) \mathrm{CH}_{4}$ emissions: g/animal/day, g/kg BW gain, g/kg DMI, g/kg digestible OM intake or MJ/MJ ME intake. 
Table 3

Effects of Marandu grass grazing height on yearling bulls growing period during the wet season.

\begin{tabular}{|c|c|c|c|c|c|c|}
\hline \multirow[t]{2}{*}{ Item } & \multicolumn{3}{|c|}{ Grazing height $(\mathrm{cm})$} & \multirow[t]{2}{*}{ SEM } & \multirow[t]{2}{*}{ Effect } & \multirow[t]{2}{*}{$P$ value } \\
\hline & 15 & 25 & 35 & & & \\
\hline \multicolumn{7}{|l|}{ Intake per animal } \\
\hline Total (kg DM/day) & 8.81 & 9.92 & 10.5 & 0.24 & Linear & 0.03 \\
\hline Herbage (kg DM/day) & 7.57 & 8.65 & 9.23 & 0.22 & Linear & 0.02 \\
\hline $\mathrm{CP} /$ digestible OM (g/kg) & 191 & 184 & 191 & 9.33 & ns & 0.21 \\
\hline ME (MJ/day) & 82.1 & 90.6 & 94.9 & 22.7 & ns & 0.19 \\
\hline \multicolumn{7}{|l|}{ Animal production } \\
\hline Stocking rate (AU/ha) & 7.11 & 5.09 & 3.91 & 0.13 & Quadratic & 0.05 \\
\hline ADG ( $\mathrm{kg} /$ animal/day) & 1.08 & 1.15 & 1.20 & 0.05 & Linear & 0.02 \\
\hline GPH (kg BW/ha) & 778 & 578 & 470 & 17.9 & Linear & 0.0002 \\
\hline \multicolumn{7}{|l|}{ Methane emissions } \\
\hline $\mathrm{CH}_{4}$ (g/animal/day) & 129 & 132 & 123 & 9.83 & ns & 0.64 \\
\hline $\mathrm{CH}_{4}(\mathrm{~kg} / \mathrm{ha} /$ day $)$ & 1.11 & 0.79 & 0.57 & 0.04 & Linear & 0.001 \\
\hline $\mathrm{CH}_{4}$ (g/kg BW gain) & 119 & 115 & 101 & 5.50 & ns & 0.09 \\
\hline $\mathrm{CH}_{4}(\mathrm{~g} / \mathrm{kg}$ DM intake) & 14.6 & 13.3 & 11.7 & 1.10 & ns & 0.40 \\
\hline $\mathrm{CH}_{4}(\mathrm{~g} / \mathrm{kg}$ digestible $\mathrm{OM}$ intake $)$ & 19.9 & 18.4 & 16.8 & 2.85 & ns & 0.71 \\
\hline $\mathrm{CH}_{4}(\mathrm{MJ} / \mathrm{MJ} \mathrm{ME}$ intake) & 0.09 & 0.08 & 0.07 & 0.01 & ns & 0.29 \\
\hline
\end{tabular}

Animal unit $(A U)=450 \mathrm{~kg}$ body weight $(\mathrm{BW})$, dry matter $(\mathrm{DM})$, organic matter $(\mathrm{OM})$, crude protein $(\mathrm{CP})$, average daily gain (ADG), gain per hectare (GPH), metabolizable energy (ME), standard error of mean (SEM) and non-significative (ns). $55.22 \mathrm{MJ} / \mathrm{kg} \mathrm{CH} 4$ (Brower, 1965).

Table 4

Characteristics of Marandu grass pastures grazed by yearling bulls during the wet season with combined grazing height and supplementation level.

\begin{tabular}{|c|c|c|c|c|c|}
\hline \multirow[t]{2}{*}{ Item } & \multicolumn{3}{|c|}{ Treatments } & \multirow[t]{2}{*}{ SEM } & \multirow[t]{2}{*}{$P$ value } \\
\hline & SHHS $^{\mathrm{a}}$ & MHMS $^{\mathrm{b}}$ & THWS $^{\mathrm{c}}$ & & \\
\hline \multicolumn{6}{|l|}{ Herbage characteristics } \\
\hline Herbage mass $(\mathrm{kg} / \mathrm{ha})$ & $5928 c$ & $7735 b$ & $10,879 a$ & 268 & $<0.0001$ \\
\hline Green leaves (g/kg) & $431 \mathrm{a}$ & 409ab & $386 \mathrm{~b}$ & 20.4 & 0.002 \\
\hline Stem + sheath $(\mathrm{g} / \mathrm{kg})$ & $399 b$ & $431 a b$ & $480 a$ & 37.7 & $<0.0001$ \\
\hline Dead material (g/kg) & 170a & $160 \mathrm{ab}$ & $134 \mathrm{~b}$ & 21.2 & 0.0002 \\
\hline Availability $^{\mathrm{d}}(\mathrm{kg} \mathrm{DM} / \mathrm{kg} \mathrm{BW})$ & $1.89 \mathrm{c}$ & $3.41 \mathrm{~b}$ & $6.17 a$ & 0.16 & $<0.0001$ \\
\hline Availability $^{\mathrm{e}}(\mathrm{kg} \mathrm{DM} / \mathrm{kg} \mathrm{BW})$ & $0.83 c$ & $1.42 \mathrm{~b}$ & $2.41 \mathrm{a}$ & 0.10 & $<0.0001$ \\
\hline \multicolumn{6}{|l|}{ Herbage composition } \\
\hline $\mathrm{OM}(\mathrm{g} / \mathrm{kg} \mathrm{DM})$ & $911 \mathrm{~b}$ & $925 a$ & $924 a$ & 32.5 & 0.004 \\
\hline $\mathrm{CP}(\mathrm{g} / \mathrm{kg} \mathrm{DM})$ & 140 & 139 & 138 & 6.62 & 0.18 \\
\hline aNDF (g/kg DM) & 588 & 600 & 590 & 48.4 & 0.44 \\
\hline $\mathrm{ADF}(\mathrm{g} / \mathrm{kg} \mathrm{DM})$ & 295 & 293 & 299 & 35.5 & 0.61 \\
\hline $\operatorname{IVDMD}(\mathrm{g} / \mathrm{kg}$ DM) & $677 a$ & $669 a$ & $650 \mathrm{~b}$ & 61.0 & 0.04 \\
\hline IVOMD (g/kg DM) & 716a & $705 a$ & $682 \mathrm{~b}$ & 55.2 & 0.04 \\
\hline GE $(\mathrm{MJ} / \mathrm{kg} \mathrm{DM})$ & $16.4 \mathrm{a}$ & $16.0 \mathrm{~b}$ & $15.7 \mathrm{c}$ & 0.15 & 0.05 \\
\hline
\end{tabular}

Dry matter (DM), body weight (BW), organic matter (OM), crude protein (CP), neutral detergent fiber (aNDF), acid detergent fiber (ADF), in vitro dry matter digestibility (IVDMD), in vitro organic matter digestibility (IVOMD), gross energy (GE), and standard error of mean (SEM). The means with different letters $(a, b, c)$ on the same line are significantly different by Tukey test $(P<0.05)$.

a SHHS: short height $(15 \mathrm{~cm})$, high supplementation $(0.6 \%$ of BW).

b MHMS: moderate height $(25 \mathrm{~cm})$, moderate supplementation $(0.3 \%$ of $\mathrm{BW})$.

c THWS: tall height $(35 \mathrm{~cm})$, without supplementation.

d Total herbage availability.

e Green leaves herbage availability.

\subsection{Experiment 2}

Herbage mass characteristics are shown in Table 4. Total herbage mass was greater in treatment THWS $(P<0.0001)$. Green leaves and dead material as proportion of the herbage biomass $(\mathrm{g} / \mathrm{kg})$ were greater in treatment SHHS than THWS $(P=0.002$ and $P=0.0002$, respectively), the opposite was exhibited on stem + sheath proportion $(P<0.0001)$. Availability of herbage mass and green leaves differed between treatments $(P<0.0001)$, being highest for treatment THWS, lowest for SHHS and intermediate for MHMS. Herbage chemical composition showed lowest OM $(P=0.004)$ in treatment SHHS. Gross energy was highest $(P=0.05)$ in treatment SHHS. Treatment THWS showed lowest IVDMD $(P=0.04)$ and IVOMD $(P=0.04)$. Grazing heights and supplementation level did not alter $\mathrm{CP}(P=0.18)$, aNDF $(P=0.44)$ and $\operatorname{ADF}(P=0.61)$ concentrations.

Animal intake, animal production and methane emissions results are shown in Table 5. Stocking rate was greatest $(P<0.0001)$ in treatment SHHS and lowest in treatment THWS Herbage DMI was lowest $(P=0.04)$ in treatment SHHS, and greatest in treatment THWS. Total DMI and the ratio CP intake/digestible OM intake were not influenced $(P=0.28$ and 0.12 , respectively) by treatments, but ME intake was greater $(P<0.0001)$ in treatment SHHS than in treatment THWS. Average daily gain was not affected $(P=0.14)$ by treatment, however GPH increased $(P<0.0001)$ with the level of supplementation 
Table 5

Effects of the combination between Marandu grass grazing height and supplementation level on yearling bulls during growing period during the wet season.

\begin{tabular}{|c|c|c|c|c|c|}
\hline \multirow[t]{2}{*}{ Item } & \multicolumn{3}{|c|}{ Treatments } & \multirow[t]{2}{*}{ SEM } & \multirow[t]{2}{*}{$P$ value } \\
\hline & SHHS & MHMS $^{\mathrm{b}}$ & THWS $^{\mathrm{C}}$ & & \\
\hline \multicolumn{6}{|l|}{ Intake per animal } \\
\hline Total (kg DM/day) & 10.6 & 9.92 & 9.74 & 0.35 & 0.28 \\
\hline Herbage (kg DM/day) & $7.98 \mathrm{~b}$ & $8.65 a b$ & $9.74 a$ & 0.29 & 0.04 \\
\hline $\mathrm{CP} /$ digestible $\mathrm{OM}(\mathrm{g} / \mathrm{kg})$ & 193 & 184 & 192 & 9.78 & 0.12 \\
\hline ME (MJ/day) & $95.9 \mathrm{a}$ & $90.6 \mathrm{ab}$ & $86.3 \mathrm{~b}$ & 2.54 & $<0.0001$ \\
\hline \multicolumn{6}{|l|}{ Animal production } \\
\hline Stocking rate (AU/ha) & $7.06 \mathrm{a}$ & $5.09 \mathrm{~b}$ & $3.96 \mathrm{c}$ & 0.22 & $<0.0001$ \\
\hline ADG (kg/animal/day) & 1.11 & 1.15 & 1.13 & 0.01 & 0.14 \\
\hline GPH (kg BW/ha) & 799a & $578 b$ & $436 c$ & 7.21 & $<0.0001$ \\
\hline \multicolumn{6}{|l|}{ Methane emissions } \\
\hline $\mathrm{CH}_{4}$ (g/animal/day) & $115 c$ & $132 b$ & 190a & 11.6 & $<0.0001$ \\
\hline $\mathrm{CH}_{4}(\mathrm{~kg} / \mathrm{ha} /$ day $)$ & $0.98 a$ & $0.79 b$ & $0.88 \mathrm{~b}$ & 0.02 & 0.0002 \\
\hline $\mathrm{CH}_{4}$ (g/kg BW gain) & $103 c$ & $115 b$ & $168 \mathrm{a}$ & 10.1 & $<0.0001$ \\
\hline $\mathrm{CH}_{4}(\mathrm{~g} / \mathrm{kg}$ DM intake $)$ & $10.8 \mathrm{c}$ & $13.3 b$ & $19.5 \mathrm{a}$ & 1.39 & 0.001 \\
\hline $\mathrm{CH}_{4}(\mathrm{~g} / \mathrm{kg}$ digestible OM intake) & $14.6 \mathrm{c}$ & $18.4 \mathrm{~b}$ & $28.6 a$ & 2.56 & $<0.0001$ \\
\hline $\mathrm{CH}_{4}(\mathrm{MJ} / \mathrm{MJ} \mathrm{ME}$ intake $)$ & $0.07 c$ & $0.08 \mathrm{~b}$ & $0.12 \mathrm{a}$ & 0.01 & 0.002 \\
\hline
\end{tabular}

Animal unit $(A U)=450 \mathrm{~kg}$ body weight (BW), dry matter (DM), organic matter (OM), crude protein (CP), average daily gain (ADG), gain per hectare (GPH), metabolizable energy (ME) and standard error of mean (SEM). $55.22 \mathrm{MJ} / \mathrm{kg} \mathrm{CH}_{4}$ (Brower, 1965). Means with different letters (a, b, c) on the same line are significantly different by Tukey test $(P<0.05)$.

a SHHS: short height $(15 \mathrm{~cm})$, high supplementation $(0.6 \%$ of $\mathrm{BW})$.

b MHMS: moderate height $(25 \mathrm{~cm})$, moderate supplementation $(0.3 \%$ of BW).

c THWS: tall height $(35 \mathrm{~cm})$, without supplementation.

combined with decreasing grazing height. Similarly, $\mathrm{CH}_{4}$ emission per ha was greater $(P=0.0002)$ for treatment SHHS compared with MHMS and THWS. In contrast, $\mathrm{CH}_{4}$ emissions: $\mathrm{g} / \mathrm{animal} / \mathrm{day}(P<0.0001), \mathrm{g} / \mathrm{kg}$ BW gain $(P<0.0001), \mathrm{g} / \mathrm{kg}$ DMI $(P=0.001), \mathrm{g} / \mathrm{kg}$ digestible OM intake $(P<0.0001)$ and $\mathrm{MJ} / \mathrm{MJ}$ ME intake $(P=0.002)$ were greatest for treatment THWS, lowest for SHHS and intermediate for MHMS.

\section{Discussion}

Sward height measurement is the main method used to manage tropical pastures due to its practicability (Da Silva et al., 2013). In both experiments, total herbage mass was affected by increasing grazing height, modifying sward structure, and modifying sward structure as reflected in the proportion of morphological components. The observed changes in stocking rate, decreasing as grazing height increased, were due to management practices needed to maintain the pre-determined grazing heights. Herbage mass is a fundamental measure of a beef grazing production system (Nave et al., 2013), with emphasis on green leaves mass since it shows the highest nutritive value. In both experiments, although the proportion of morphological components has been altered, pastures with higher grazing height resulted in higher green leaves mass per hectare, higher stem + sheath, and higher dead material mass.

Grazing intensity can affect herbage nutritive value (Da Silva et al., 2013; Vendramini et al., 2013). In both experiments, there were no observed differences in aNDF and ADF values. However, the IVDMD and IVOMD showed a linear negative response as grazing height was increased in the first experiment and showed higher values when combining low grazing height and high supplementation level in the second experiment. This is associated with the increased of stem + sheath proportion (Bircham and Hodgson, 1983), decrease of green leaves proportion, and decrease in overall herbage nutritive value (Van Soest, 1994). In both experiments stocking rate was affected by treatments. This response was due to grazing intensification since it is usually necessary to increase stocking rate to maintain a lower grazing height (Mott, 1960; Barbero et al., 2014).

Herbage DMI may be altered by grazing intensity (Da Silva et al., 2013) and energy supplementation (Moore et al., 1999). The linear response observed for herbage DMI in the first experiment may be explained by the same response showed by green leaves allowance, where the highest allowance resulted in greater herbage intake when supplementation level was maintained constant for all pasture heights. This response was also observed for total DMI. Using different supplementation levels associated with different grazing heights in the Exp. 2, also resulted in lower herbage DMI in treatment SHHS and greater intake in treatment THWS.

Detmann et al. (2014) studied $\mathrm{N}$ use efficiency by beef cattle supplemented in tropical pastures and showed maximum efficiency at $200 \mathrm{~g} \mathrm{CP}$ intake/kg digestible OM intake. Despite the differences in herbage DMI in Exp. 1, supplementation resulted in the same ME intake and the same $\mathrm{CP}$ intake/digestible OM intake relationship. In Exp. 2, ME intake was higher for treatments SHHS and MHMS as compared with THWS but the CP intake/digestible OM intake relationship was not affected. The relationships between $\mathrm{CP}$ intake and digestible $\mathrm{OM}$ intake recorded in both experiments were similar and close to values proposed by Detmann et al. (2014) for the maximum efficiency of $\mathrm{N}$ use. These results suggest that although energy was 
prioritized in the supplement formulation based on herbage characteristics, protein was not limiting for the conditions of this study. Thus, in conditions of well-managed tropical pastures, energy supplementation can be studied as a way to balance and utilize nutrients efficiently.

Average daily gain is associated with intake and digestibility of nutrients (Reis et al., 2013). As a consequence of the linear increase in total DMI, ADG increased with grazing height in the first experiment. This may suggest that the same supplementation level was not enough to maintain animal performance when different grazing heights are used for beef cattle. Although GPH increased as grazing height decreased, this was associated to a decrease of individual ADG, resulting in a lower BW at the end of the experimental period. In the study of Da Silva et al. (2013), heifers grazing tall Marandu grass $(40 \mathrm{~cm}$ ) had an ADG close to $1.0 \mathrm{~kg} /$ day showing the production potential of this tropical pasture. In the Exp. 2, treatment THWS resulted in CP intake (1.2 kg/day) in accordance with requirements estimated for the predicted ADG of $1.0 \mathrm{~kg} / \mathrm{day}$ for growing bulls by NRC (1996).

According to Mott (1960), it is difficult to simultaneously improve individual ADG and GPH under grazing conditions. However, in Exp. 2, combining grazing height with supplement level did result in similar ADG while GPH was increased by decreasing grazing height. These results suggest that the association between grazing pressure and supplementation level is the best way to achieve efficiency when producing beef cattle in tropical pastures during the wet season. Maintaining a lower grazing height associated with supplements seems to be the key to system efficiency. However, the intensification of production systems with high grazing pressure resulting in pastures with lower grazing height has to be carefully considered. Although these systems will result in greater productivity, lower herbage mass can result in unavailable pastures during the dry season. In drought conditions, pasture degradation may also occur. In this case, finishing animals in a feedlot system should be considered.

Different grazing heights associated with the same supplementation level did not affect the $\mathrm{CH}_{4}$ emissions per animal in Exp. 1, but the production of $\mathrm{CH}_{4} /$ ha increased when grazing height was decreased, probably due to high grazing density in pastures managed with lower grazing height, since $\mathrm{CH}_{4}$ emission per hectare is the product of individual $\mathrm{CH}_{4}$ emission by stocking rate. This also explains the greater $\mathrm{CH}_{4}$ emission per hectare in treatment SHHS (Exp. 2) in spite of having lower individual $\mathrm{CH}_{4}$ emission. According to Boland et al. (2013), the increase in herbage nutritive value is highly correlated with the decrease in $\mathrm{CH}_{4}$ emission. The individual average yearly $\mathrm{CH}_{4}$ emission from young beef cattle in the Latin America is $49 \mathrm{~kg} /$ year, with daily average of $134 \mathrm{~g} /$ day (IPCC, 2006) which is similar to values recorded in Exp. 1, although emissions of $\mathrm{CH}_{4}$ in Exp. 2 were lower and higher in treatments SHHS and THWS, respectively, than the value reported by IPCC. The greater individual $\mathrm{CH}_{4}$ emission by bulls in the treatment THWS can be explained by the exclusive feeding on grass of lower ME and IVOMD than the supplement. However $\mathrm{CH}_{4}$ emission per hectare was lower than in SHHS treatment due to lower stocking rate. However, variations in herbage nutritive value and supplementation throughout the season are expected.

Disposal of fermentation products by ruminal methanogenesis can be affected by supplementation with starchy feeds that reduce the $\mathrm{H}_{2}$ supply to the methanogenic population by increasing the production of propionic acid (Morgavi et al., 2010). In Exp. 1, different grazing height did not alter the $\mathrm{CH}_{4}$ emission when expressed in relation to BW gain, DMI, digestible OM intake or as proportion of ME intake ( $\mathrm{MJ} \mathrm{CH}_{4} / \mathrm{MJ}$ ME intake). However, in Exp. 2, the modulation of supplementation according to grazing height provides the opportunity to reduce $\mathrm{CH}_{4}$ emission without affecting ADG as shown by treatments SHHS and MHMS which recorded lower $\mathrm{CH}_{4}$ emissions, whether expressed in individual animal basis, per $\mathrm{kg}$ of $\mathrm{BW}$ gain or as proportion of ME intake, as compared to grass feeding without supplement in treatment THWS.

\section{Conclusion}

The results of this study show that supplementation can decrease $\mathrm{CH}_{4}$ emission per ADG. Beef cattle production systems using tropical forages during the wet season should consider grazing intensity and supplementation in order to increase the overall system efficiency in terms of GPH and $\mathrm{CH}_{4}$ emission but maintaining a high ADG per animal.

\section{Conflict of interest statement}

We declare that there is not conflict of interests in this project. Additionally, there is no financial or other relationship with other people or organizations that may inappropriately influence the author's work.

\section{Acknowledgements}

The authors would like to thank the "São Paulo Research Foundation" (FAPESP grants \#2011/00060-8, \#2012/14956-6, \#2012/20264-0, and \#2013/25202-5) and "Trouw Nutrition Brasil" for their financial support, and the Plateau Research and Education Center (PREC), University of Tennessee, for their cooperation. The authors also would like to thank the anonymous reviewers for their helpful and constructive comments that greatly contributed to improving of this paper.

\section{References}


Barbero, R.P., Barbosa, M.A.F.B., Castro, L.M., Ribeiro, E.L.A., Mizubuti, I.Y., Bumbieris Júnior, V.H., Silva, L.D.F., Massaro Júnior, F.L., 2014. Desempenho de novilhos de corte em pastos de capim-tanzânia sob quatro alturas de desfolha. Arq. Bras. Med. Vet. Zootec. 66, 481-488.

Bircham, J.S., Hodgson, J., 1983. The influence of sward condition on rates of herbage growth and senescence in mixed swards under continuous stocking management. Grass Forage Sci. 38, 323-331

Boland, T.M., Quinlan, C., Pierce, K.M., Lynch, M.B., Kelly, A.K., Purcell, P.J., 2013. The effect of pasture pre-grazing herbage mass on methane emissions, ruminal fermentation, and average daily gain of grazing beef heifers. J. Anim. Sci. 8, 3867-3874.

Brower, E., 1965. Report of subcommittee on constants and factors. In: Blaxter, K.L. (Ed.), Proceedings of the 3 Symposium on energy Metabolism. London, England, pp. 441-443.

Casali, A., Detmann, E., Valadares Filho, S.C., 2008. Influência do tempo de incubação e do tamanho de partículas sobre os teores de compostos indigestíveis em alimentos e fezes bovinas obtidos por procedimentos in situ. Rev. Bras. Zoot. 37, $335-342$.

Da Silva, S.C., Gimenes, F.M.A., Sarmento, D.O., Sbrissia, A.F., Oliveira, D.E., Hernadez-Garay, A., Pires, A.V., 2013. Grazing behaviour, herbage intake and animal performance of beef cattle heifers on Marandu palisade grass subjected to intensities of continuous stocking management. J. Agric. Sci. 151, 727-739.

De Oliveira, A.P., Casagrande, D.R., Bertipaglia, L.M.A., Barbero, R.P., Berchielli, T.T., Ruggieri, A.C., Reis, R.A., 2015. Supplementation for beef cattle on Marandu grass pastures with different herbage allowances. Anim. Prod. Sci. 53, 1-7.

Detmann, E., Valente, E.E.L., Batista, E.D., Huhtanen, P., 2014. An evaluation of the performance and efficiency of nitrogen utilization in cattle fed tropical grass pastures with supplementation. Livest. Sci. 162, 141-153.

Fiorentini, G., Messana, J.D., Dian, P.H.M., Reis, R.A., Canesin, R.C., Pires, A.V., Berchielli, T.T., 2013. Digestibility, fermentation and rumen microbiota of crossbred heifers fed diets with different soybean oil availabilities in the rumen. Anim. Feed Sci. Technol. 181, 26-34.

Intergovernmental Panel on Climate Change (IPCC), 2006. IPCC guidelines for national greenhouse gas inventories. In: Eggleston, H., Buendia, L., Miwa, K. Ngara, T., Tanabe, K. (Eds.), The National Greenhouse Gas Inventories Programme, Intergovernmental Panel on Climate Change. IGES, Japan.

Johnson, K.A., Huyler, M., Westburg, H., Lamb, B., Zimmerman, P., 1994. Measurement of methane emissions from ruminant livestock using a SF 6 tracer technique. Environ. Sci. Technol. 28, 359-362.

Jones, R.J., Sandland, R.L., 1974. The relation between animal gain and stocking rate. J. Agric. Sci. 83, $335-342$.

Mertens, D.R., 2002. Gravimetric determination of amylase-treated neutral detergent fiber in feeds with refluxing beakers or crucibles: collaborative study. J. Assoc. Off. Assoc. Chem. Int. 85, 1217-1240.

Moore, J.E., Brant, M.H., Kunkle, W.E., Hopkins, D.I., 1999. Effects of supplementation on voluntary forage intake, diet digestibility, and animal performance. J. Anim. Sci. 77, 122-135.

Morgavi, D.P., Forano, E., Martin, C., Newbold, C.J., 2010. Microbial ecosystem and methanogenesis in ruminants. Animal 4, $124-1036$.

Mott, G.O., 1960. Grazing pressure and the measurement of pasture production. In: International Grassland Congress, 8, Reading, United Kingdom, pp. 606-611.

Mott, G.O., Lucas, H.L., 1952. The design, conduct and interpretation of grazing trials on cultivated and improved pastures. In: Proceedings of the Sixth International Grassland Congress, Pennsylvania, pp. 1380-1385.

Myers, W.D., Ludden, P.A., Nayigihugu, V., Hess, B.W., 2004. Technical note: a procedure for the preparation and quantitative analysis of samples for titanium dioxide. J. Anim. Sci. 82, 179-183.

Nave, R.L.G., Sulc, R.M., Barker, D.J., 2013. Relationships of forage nutritive value to cool-season grass canopy characteristics. Crop Sci. 53, $341-348$.

Nocek, J.E., English, J.E., 1986. In situ degradation kinetics: evaluation of rate determination procedure. J. Dairy Sci. 69, $77-87$.

NRC, 1996. Nutrient Requirements of Beef Cattle, 7th ed. Natl. Acad. Press, Washington, DC.

Reis, R.A., Valente, A.L.S., Santos, S.M.C., Souza, F.H.M., Berchielli, T.T., Ruggieri, A.C., Santana, S.S., Serra, J.M., 2013. Performance of young Nelore bulls grazing Marandu grass pasture at different heights. Trop. Grassl. 1, 114-115.

Saliba, E.O.S., Gonçalves, N.C., Barbosa, G.S.S.C., Borges, A.L.C.C., Rodriguez, N.M., Moreira, G.R., Silva, F.A., 2013. Evaluation of the infrared spectroscopy method for the quantification of nanolipe marker in feces of dairy cattle. In: Oltjen, J.W., Kebreab, E., Lapierre, H. (Eds.), Energy and Protein Metabolism and Nutrition in Sustainable Animal Production. CA, USA. , pp. 247-248.

Santos, A.S., Valadares Filho, S.C., Detmann, E., Valadares, R.F.D., Ruas, J.R.M., Amaral, P.M., 2011. Different forage sources for F1 Holstein ×Gir dairy cows. Livest. Sci. 142, 48-58.

SAS Institute, 2008. SAS/STAT 9.2 User's Guide. SAS Institute, Cary, NC.

Sollenberger, L.E., Vanzant, E.S., 2011. Interrelationships among forage nutritive value and quantity and individual animal performance. Crop Sci. 51, 420-432.

Titgemeyer, E.C., Armendariz, C.K., Bindel, D.J., Greenwood, R.H., Löest, C.A., 2001. Evaluation of titanium dioxide as a digestibility marker for cattle. J. Anim. Sci. 79, 1059-1063.

Van Soest, P.J., 1994. Nutritional Ecology of the Ruminant, 2nd ed. Cornell Univ. Press, Ithaca, NY, USA.

Vendramini, J.M.B., Sollenberger, L.E., Blount, A.R., Aguiar, A.D., Galzerano, L., Valente, A.L.S., Alves, E., Custodio, L., 2013. Bahiagrass cultivar response to grazing frequency with limited nitrogen fertilization. Agron. J. 105, 938-944 